\title{
Göstergebilimin Kuramsal Açıdan İncelenmesine Yönelik Bir Araştırma ${ }^{1}$ \\ (Araştırma Makalesi)
}

\author{
A Research on Theoretical Analysis of Semiotics \\ Doi: 10.29023/alanyaakademik.683974
}

Makbule CIVELEK

Dr. Öğr. Üyesi, Zonguldak Bülent Ecevit Üniversitesi, KDZ Ereğli Turizm Fakültesi. makbule.civelek@beun.edu.tr

Orcid No: 0000-0002-3997-6508

\section{Oğuz TÜRKAY}

Prof. Dr., Sakarya Uygulamalı Bilimler Üniverstitesi, Turizm Fakültesi.

turkay@subu.edu.tr

Orcid No: 0000-0002-0752-6799

Bu makaleye atıfta bulunmak için: Civelek M., Oğuz T. (2020). "Göstergebilimin Kuramsal Açıdan Incelenmesine Yönelik Bir Araştırma”, Alanya Akademik Bakış, 4(3), Sayfa No.771-787.

\begin{tabular}{|c|c|}
\hline & ÖZET \\
\hline $\begin{array}{l}\text { Anahtar kelimeler: } \\
\text { Göstergebilimsel } \\
\text { Anlamlandırma, } \\
\text { Göstergebilimin } \\
\text { Tarihsel Süreci, } \\
\text { Göstergebilimsel } \\
\text { Analiz. } \\
\text { Makale Geliş Tarihi: } \\
\text { 03.02.2020 } \\
\text { Kabul Tarihi: } \\
\text { 02.09.2020 }\end{array}$ & 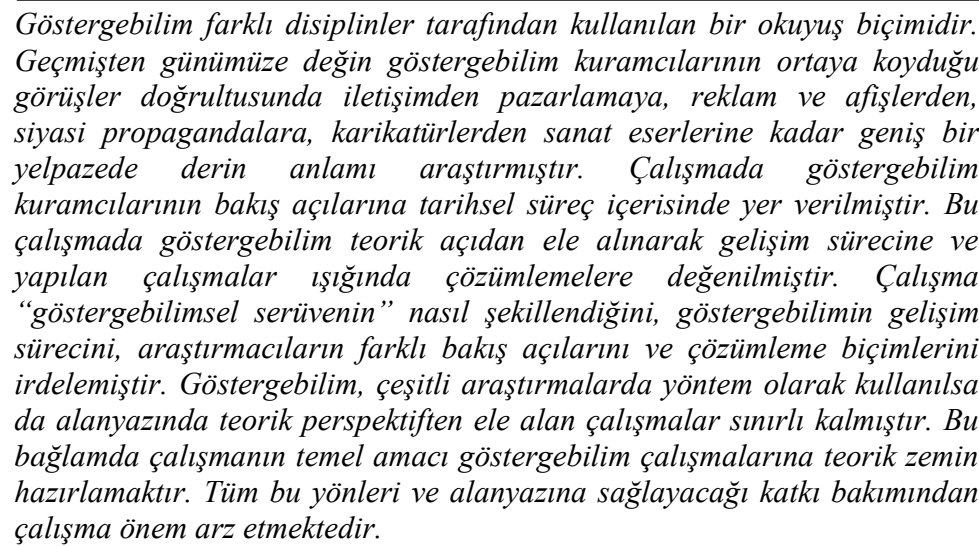 \\
\hline
\end{tabular}

\footnotetext{
${ }^{1}$ Bu makale, Sakarya Üniversitesi, Sosyal Bilimler Enstitüsü Turizm İşletmeciliği Anabilim Dalı’nda Prof. Dr. Oğuz TÜRKAY danışmanlığında Makbule CiVELEK tarafından tamamlanan "Tanıtım Filmlerinin Turizm Açısından Göstergebilimsel Bir Çözümlemesi: Türkiye Örneği” adlı Doktora Tezinden üretilmiştir.
} 
Keywords:

Semiotic Semantics, Historical Process of Semiotics, Semiotic Analysis

\begin{abstract}
Semiotics is a form of reading used by different disciplines. In line with the views of semiotic theorists from the past to the present, he explored a wide range of profound meanings, from communication to marketing from advertising and posters, to political propaganda, from caricatures to works of art. In the study, the perspectives of semiotics theorists are included in the historical process. In this study, semiotics is discussed from a theoretical point of view, and the development process and the analysis in the light of the studies that have been poured out are addressed. The study examined how the "semiotic adventure" took shape, the development process of semiotics, the different perspectives of the researchers and the ways of analysis. Although semiotics is used as a method in various researches, studies dealing with the theoretical perspective in the literature have been limited. In this context, the main purpose of the study is to prepare theoretical ground for semiotics studies. The study is important in terms of all these aspects and its contribution to the literature.
\end{abstract}

\section{GİRIŞ}

Göstergebilim, bir kültüre özgü olsun ya da olmasın metinlerin çözümlenmesini ifade etmektedir. Metin, göstergebilimin konusuna giren herşeydir. Bir müzik notasından, tabloya, reklam afişinden kültüre özgü davranışlara, sinema filminden, tiyatro gösterilerilerine, şiirden romana kadar metinler çeşitlilik göstermektedir. Metinler, göstergelerin sistematik olarak çözümlenerek derin anlam yüzeyine ulaşmasını sağlamaktadır. Görünen anlamın dışındaki anlama odaklanan göstergebilim, anlamı parçalara ayırır. Mitler, metaforlar ve kodlar aracılığıyla anlamı tekrar inşa eder.

Göstergebilim, tarihsel süreç içerisinde farklı disiplinlerin ilgi odağı olmuştur. Pazarlamadan iletişim bilimine, insan davranışlarından sosyo-kültürel yapıya değin geniş bir okuma sürecini kapsamaktadır. Göstergebilimin bir alana özgü olmaması göstergebilimsel çözümlemelerinin çeşitlenmesini beraberinde getirmiştir. Araştırmacılar göstergebilimin farklı okuma biçimlerinden yararlanrak hareket etmiştir. Bilimsel bilginin birikimsel olması göstergebilimin gelişmesine de olanak tanımıştır. Tarihsel süreç içerisinde Peirce ve Saussure farklı ülklelerde benzer bakış açılarıyla göstergebilimin temellerini ortaya koymuştur. Araştırmacılar göstergebilimsel okuyuş düzeylerini sistemize ederek öznellikten sıyrılmasını sağlamıştır. Göstergebilimsel çözümlemeler genel olarak iki kuramcı etrafında şekillenmiştir. Bunun yanısıra göstergebilime bilimsel açıdan yaklaşan Eco, yananlam düzeyde okumayı beraberinde getiren Barthes, karşıtlıkları çözümleyen Gremias da araştırmacılara yol göstren göstergebilimsel çözümlemeleri oluşturmuştur.

Çalışma, göstergebilimi ve göstergebilimsel yaklaşımları kuramsal açıdan incelemeyi hedeflemektedir. Göstergebilimi konu alan çalışmalar genel itibari ile yöntemsel bakımdan göstergebilimi ele almaktadır. Bu nedenle göstergebilimin kuramsal açıdan ele alınması alanyazında bu boşluğu dolduracağı düşünülmektedir. Bu çalışmada kuramsal perspektif ile göstergebilimin temelleri, gelişim süreci ve kuramcıların bakış açıları ile göstergebilimsel serüven incelenmiştir.

Göstergebilimi konu alan bu çalışma iki temel bölümden oluşmaktadır. İlk bölümde göstergebilimin kuramsal çerçevesi belirlenirken; göstergebilim kavramı, anlamlandırma, 
göstergebilimin amacı, inceleme alanı, tarihsel süreç içerisindeki gelişimi ve kuramcıların bakış açıları anlatılmıştır. İkinci bölüm göstergebilim çözümlemelerini kapsamaktadır. Yapılan çalışmalara yer verilen bu bölümde çözümlemeler dizisel ve dizilimsel çözümlemeler, görüntü çözümlemeleri ve sanatsal çözümlemelerden oluşmuştur.

\section{GÖSTERGEBILIMIN KURAMSAL ÇERÇEVESI}

\subsection{Göstergebilim Kavramı ve Anlamlandırılması}

Göstergebilim araştırmacılar tarafından çeşitli bakış açıları ile tanımlanmıştır. Göstergebilim en genel haliyle "gösterge ve bilim" kavramlarının birleşiminden oluşmaktadır. Araştırmacılar tarafından (Çiçek, 2014: 215; Sayın 2014: 33; Ünal, 2014: 3; MacCannell, 2013: 109; Aktulum, 2004: 2; Kıran, 2004: 51; Guiraud, 1994: 17) gösterge olarak vurgu yapılan unsur, "maddi ve soyut her şey"i kapsamaktadır. Bu tanımlamalardaki odak noktası göstergebilimin, "göstergelerin bilimini yapmayı amaç edinen bir bilim dalı" olmasından ileri gelmektedir.

Göstergebilimi iletişim yönünü ortaya koyan akademisyenler (Parsa ve Parsa, 2012: 1-2; Oswald, 2011: 19; Erkman, 1986: 11) göstergebilimin "iletişimin ön plana alınarak göstergelerin incelenmesi," "iletişime geçilebilecek her olgunun çözümlenmesi," "beden hareketlerinin ve ritüellerin çözümlenmesi” olarak ifade etmiştir. Bu tanımlamalardaki esas amaç göstergebilimin inceleme alanına girecek olan olguların saptanması yönünde olmuştur.

Bir başka grup akademisyen (Rifat, 2014a: 113; Ardıç-Çobaner, 2013: 220; Berkeley, 2012: 3; Guiraud, 1994: 17) göstergebilimi "anlamın eklemleniş biçimi”" olarak ifade etmiştir. Bu tanımlamalarda vurgu yapılan noktalar "gösterge dizgelerinin arasındaki ilişkiyi açıklama," "göstergelerin anlamlandırılma sürecinde eklemlenme biçimlerini anlama," "anlamlı bütünleri oluşturan unsurları parçalara bölerek anlamı çözümleme," "anlamın ne olduğunu analiz etme" olarak sıralamak mümkündür. Bu tanımlamalar göstergebilimin olguları ve nesneleri anlamlandırma ve anlamı inşa etme ilişkisine vurgu yapmıştır.

Yapılan tanımlamalar birbirinden farklılık gösterse de bu tanımlamalara ilişkin özellikleri bir çatı etrafında toplamak mümkündür. Bu tanımlardan yola çıkılarak göstergebilime ilişkin aşağıdaki özelliklere ulaşılabilir:

- Göstergebilim, olay ve olgulara değişik bakış açıları ile geniş bir perspektiften bakmayı mümkün kılar.

- Göstergebilim, anlamın nasıl inşa edildiğini, görünen anlamın dışındaki derin anlamı ortaya koymaya çalışır.

- Göstergebilim, bir etkileşim sürecini ifade etmektedir. Çözümleme yapılacak metinler üzerinde ilişki kurmayı ve anlamsal çıkarımlar yapmayı sağlamaktadır.

- Göstergebilim, anlamlı bir bütünü parçalara ayırarak çözümlemeyi mümkün kılar.

- Göstergebilim, tüm parçaların arasındaki anlamsal bağı saptamaya çalışır.

- Göstergebilim; gösterge, gösteren ve gösterilen ilişkisini sistemli bir şekilde incelemeye olanak tanır.

Akademisyenlere göre (Sayın, 2014: 117; Gottdiener, 2005: 41; Günay, 2002: 186) göstergebilimin temel alanı anlamdır. Göstegebilim anlamın nasıl oluştuğu, görünen anlamın ötesindeki anlamın ne olduğu ve anlamsal olarak yüzeysel boyuttan derin boyuta nasıl 
geçilebileceği üzerine odaklanır. Sayın (2014: 117) göstergebilimde anlamlandırmanın önemini "göstergebilimde merkezi bir yer işgal etme" olarak ifade etmektedir. Anlam ve anlamlandırma insanın etrafındaki nesnelere ve olgulara nitelik kazandırmasıdır. Bu anlamlandırma sürecinde zihnimizde kavramlar oluşmaktadır. Kavramlar da zaman içerisinde zihnimize yerleşerek bilinçlenmeyi sağlamaktadır. Guiraud (1999: 23) bu görüşü; bir nesnenin ya da varlığın zihnimizde canlandırdığı ve bağladığı kavram olarak özetlemektedir.

Göstergebilime göre anlamlandırma karşıtlıklardan doğar (Günay, 2002: 160) ve bu karşıtlıklara göre şekillenir. Anlamlandırma aşamasında okunan metinin niteliği her ne olursa olsun, dizgeleri anlamlı bir biçimde okuyarak, kodların çözümlenmesi gerekmektedir. Sayın’a (2014: 51) göre ise insan-doğa, insan-insan ilişkilerini anlamlandıran göstergebilimde iki aşamalı bir anlamlandırma vardır. İlk aşamada bireyler evreni ve kendini anlamlandırır. İkinci aşamada kendini ve evreni anlamlandıran insan anlamın oluşabilmesi için kodları kullanarak çevresini çözümler. Göstergebilimsel anlamlandırmada işaretlerin ve kültürel kodların karakteristik yapıları ve çözümlemeleri yorumlayana bağlıdır (Echtner, 1999: 4). Göstergebilime göre anlamlama ya da göstergelerin üretimiyle tüketimi ussal bir süreçtir. Böylece nesnel dünya göstergenin dolayımsız bir parçası değildir (Gottdiener, 2005: 23).

Göstergebilim, anlamlandırma sürecinin nasıl gerçekleştiğini, birincil anlamın dışındaki anlamsal değişimi göstermeye çalışır. Görünen ve bilinen anlamın dışına çıkarak derin anlama ulaşma sürecini kapsar. $\mathrm{Bu}$ süreç içerisinde ise göstergebilim, göstergelerden hareketle çözümlemeler yapmayı mümkün kılmaktadır. Yapılan çözümlemeler öznel bir okuyuştan yola çıksa da, kültürel kodların çözümleniyor olması sebebiyle aynı zamanda objektiflik taşımaktadır.

\subsection{Göstergebilimin Amacı ve İnceleme Alanı}

Göstergebilimin amacı davranış biçimleri, yaşam tarzları, nezaket kuralları, beden dilleri, giyim tarzları, toplumsal ve kültürel yapı, sinema, reklam, tiyatro, müzik notaları gibi sanatsal faaliyetler, astronomi, mimari ve dizayn (Barthes, 2016: 27; Parsa ve Parsa, 2012: 1-2; Rifat, 2011: 91; Kıran, 2009: 12-13; Eco, 2004: 236; Erkman, 1986: 11; Vardar, 1982: 61) gibi birçok alanda işleyiş yapılarını ortaya koymaktır. Bu amaç doğrultusunda işleyiş kurallarını oluşturarak çözümleme yapmaya olanak tanımaktadır. Çözümlemeler esnasında "her türlü iletişim sürecini bir metin olarak okuma" (Elgün vd., 2013: 75) amacı taşır. Okuma sürecinde ise oluşturmuş olduğu yapıyı değişik bakış açıları ile irdeleyerek, bu yapılar arasında bağlantılar kurmayı hedefler (Kıran, 2004: 51).

Göstergebilim, izole edilmiş anlamın içeriğini tayin ederek, bir içerikle doğrulanmış özellikleriyle anlamı, anlamın ne olduğunu analiz etmektedir (Berkeley, 2012: 3). Oswald'a (2011: 37-38) göre göstergebilimin amacı; anlama ve anlamlandırmaktır. Göstergebilim anlamını yapılandırmak amacıyla kültürel kodlara yönelerek, popüler kültürden eserlerin analiz edilmesini sağlar. Veri toplama amacıyla yenilikçi yaklaşımların, kodların ve kültürel eğilimlerin saptanmasını beraberinde getirmektedir.

Göstergebilim çeşitli konularla ilgilendiği için konusu iletişim olan her şeyi inceleme alanı (Parsa ve Parsa, 2012: 2; Erkman, 1986: 22) olarak görmektedir. Aynı zamanda göstergeler arasında bir bağlantı kurarak iletişim sağlama mekanizmasını araştırır. Bu bağlamda da göstergebilim nitelik üzerinde durur. Nicelik ile ilgilenmez. Parsa ve Parsa (2012: 2) bunun 
nedenini göstergelerin toplumsal yapı ve gruplar için taşıdığı anlamın önemli olması yönünde açıklamaktadır.

Göstergebilimin inceleme alanının sınırlarını çizebilmek adına çeşitli sorular sormaktadır. Anlamın oluşumu, anlamın inşası, anlamın işleyişi ve işlevinin ne olduğu (Kıran, 2009: 3) gibi betimleyici soruların yanı sıra dünyayı ve insanı anlama, yaşam biçimlerini ortaya koyma (Yücel, 2012: 93), farklı yaşam alanlarına ilişkin sorunların üstesinden nasıl gelindiğini saptama (Erkman-Akerson, 2016: 16) gibi daha genel sorulara da yanıt aramaktadır. Göstegebilim bu soruların yanıtlarını ararken aynı zamanda bilgi birikimi ile kendi içerisinde gelişimini sağlamaktadır. Öztokat (2014: 135) bunu "toplumsal ve ekinsel devingenliğine uygun biçimde hareket etme” olarak ifade etmektedir.

Fiske (2014: 122) göstergebilimin çalışma alanını sistemize ederek üçe ayırmıştır. Bunlardan ilki "göstergenin kendisi"' dir. Buradaki amaç göstergelerin kullanım amacına göre diğer unsurlara ilişkilendirilmesidir. İkincisi "içinde göstergelerin düzenlendiği kodlar ya da sistemler"den oluşmaktadır. Toplumu ve kültürel ihtiyaçları ortaya koymak adına kodlar oluşturulur. Bu kodlar iletişim kanalları aracılığ 1 ile iletilir. Göstergebilimin son çalışma alanı "kodlar ve göstergelerin içinde işlediği kültür”den meydana gelmektedir. Esas amaç kültürü oluşturan kodların çözümlenmesidir.

\subsection{Göstergebilim Kuramları}

Göstergebilimin tarihsel süreç içerisindeki gelişimi incelendiğinde ilk insanların iletişimine gönderme yapmak mümkündür. İlk insanların iletişimi somuttan soyuta doğru giden bir yol izlemiştir. Böylece iletişimde ortaya çıkan temel araç olarak dil gelişmiştir. Dil göstergelerden oluşan bir dizgedir. Dilsel göstergelerin iki düzlem içerdiğini söyleyebiliriz. $\mathrm{Bu}$ düzlemlerden birincisini sesler oluşturmaktadır. Bu sesler belli bir biçim alınca anlamlı sözcükler ortaya çıkar. Bu sözcüklerin kodlarını bilen aynı toplumun üyeleri de işte bu ortak bilme yoluyla iletişim kurabilirler. İkinci düzlem ise kavramlardır. Kavramlar zihnimizde oluşur. Bunlar ortaya çıktıklarında birer gösteren olarak belirirler. Yani kavramların bir gösterileni vardır. Aristotelesçi ve Aydınlanmacı düşünürlerde dış dünya, zihnimize olduğu gibi yansır ve sözcükler bu yansımaların, dış dünyanın temsilcisi olarak düşünülür, fikirler değişmez bir dünyanın izdüşümü olarak kabul edilir. Antik dönem düşünürlerinden özellikle Platon ve Aristoteles'in bugün bizim göstergebilim olarak tanımladığımız alanın temel fikrini inşa ettikleri görülmektedir (Sayın, 2014: 17).

Ortaçağda skolastik felsefeciler anlamlama biçimleri ile ilgilenmişler, içerik ile biçim arasındaki ilişki üstünde durmuşlardır. Daha sonraki yüzyıllarda başta Locke ve Lambert olmak üzere birçok felsefeci anlam taşıyan biçimlerin ve göstergelerin öğretisi üstüne düşünmüş, Locke "An Essay Concerning Human Understanding (Insan Anlı̆̆l Üzerine Bir Deneme" adlı yapıtında bilimleri sınıflandırırken mantık (logike) olarak adlandırdığı göstergeler öğretisi (ya da göstergeler bilgisi) anlamına gelen semeiotike'ye yer vermiştir (Rifat, 2013: 99).

Göstergebilim Amerikalı filozof C.S. Peirce'ın çalışmasıyla (kökleri ortaçă̆ felsefesine dayanmasına rağmen) ve İmbilimci İsviçreli dilci Ferdinand de Saussure'ün çalışmasıyla ilişkilendirilir. Her ikisi de anlamın nasıl üretildiği ve nakledildiği ile ilgilenir (Berger, 2012: 82). Göstergebilimin günümüz gelişiminde Avrupa göstergebilimi çerçevesi rol oynamaktadır. Göstergebilim, Hjelmslev, Greimas, Jakobson ve Kristeva gibi kuramcilar etrafında şekillenmiştir (Parsa ve Parsa, 2012: 6). Tarihsel süreç içerisinde gelişim gösteren 
göstergebilimi etkileyen toplumsal etmenlerden bahsetmek mümkündür. $\mathrm{Bu}$ etmenleri Erkman-Akerson (2016: 74-76) aşağıdaki gibi sıralamaktadır.

- Farklı ülkeler ve topluluklar arasındaki ilişkilerin yoğunlaşması (yabancı dil öğrenme zorunluluğu),

- İletişimin büyük bir hızla gelişmesi (kitlelere kolaylıkla ulaşabilme),

- Yüzeysel içerikli metinlerin yaygınlaşması (kolay tüketilecek, basit metinlerin yaygınlaşması),

- Her yeri reklamların kaplaması (tüketim furyası ve yapay gereksinimler yaratılması),

- Geleneksel değerlerin hiç olmadığı gibi sorgulanmaya başlanması ve bütün bunların sonucunda, büyük kitlelere belli bir yaşam tarzının dayatılması.

\subsubsection{Ferdinand de Saussure}

Saussure göstergebilimin Avrupa'daki öncüsüdür. Ölümünden hemen sonra öğrencileri ders kapsamındaki notları toparlayarak "Cours de Linguistique Generale (Genel Dilbilim Dersleri)" isimli kitabı yayımlamışlardır. Saussure dil dışındaki göstergelerin diğer göstergelerden ayrışması gerektiğini savunmuştur (Rifat, 2014a: 120). Bu tezi ErkmanAkerson (2016: 60) "göstergebilim, ileride kurulacak bir bilim dall" şeklinde aktarmıştır. Saussure göstergeleri gösteren ve gösterilen olmak üzere iki bölüme ayrılmaktadır. Gösteren ses, imaj olarak tanımlanırken, gösterilen ise bir kavramdır. Gösteren fiziksel ya da duyusal nesneye göre şekil alırken, gösterilen psikolojik nesneye göre şekil alır (Berkeley, 2012: 6). Ek olarak Saussure kavramların tek başlarına bir anlam ifade etmediklerini öne sürer. Anlamlarını yalnızca ilişkisel olarak ya da karşılıklı olarak kazanırlar (Berger, 2012: 82). Saussure, gösterileni zihnimizdeki soyut kavram, göstereni ise somut dişavurum biçimi olarak ifade etmektedir. Dili konuşanlar arasındaki uzlaşımsal bağ çözümleme sürecinde de rol oynamaktadır. Örneğin kâğıt dediğimizde Türkçe bilen bir kişinin zihninde oluşacak olan görüntü ve algılama biçimi, bu dili bilmeyen bir kişide aynı etkiyi göstermeyecektir. Bu nedenle dil ortak kültürel kodların algılanması ve yorumlanmasında önemli bir rol oynamaktadir.

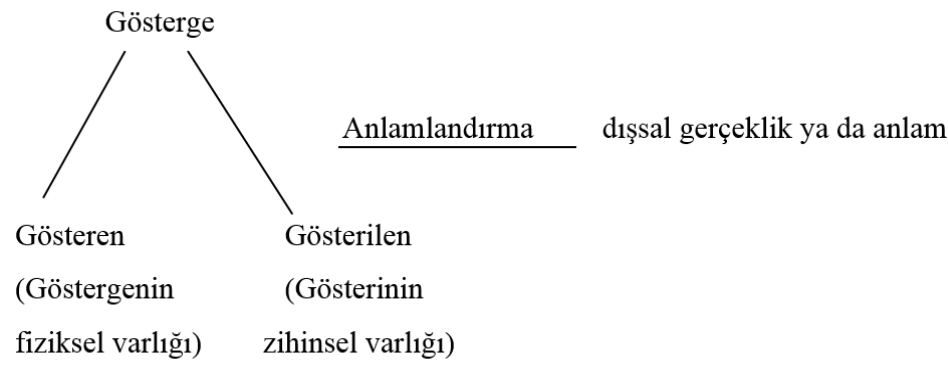

Şekil 1. Saussure'ün Anlam Öğeleri

Kaynak: Fiske 2014: 12.

\subsubsection{Charles Sanders Peirce}

Peirce göstergebilim terimini ilk kez kullanan akademisyenlerdendir (Erkman, 1986: 28). Mantık ve göstergebilim arasında bir bağlantı kurmaya çalışarak göstergebilimi felsefe ve mantık üzerinden yorumlamıştır (Çiçek, 2014: 217; Erkman, 1986: 28). Bu yaklaşım da Peirce'i toplumsallıktan uzaklaştırmış, göstergebilimi özne zihninin bir ürünü olarak 776 
göstermeye çalışmıştır (Sayın, 2014: 47-48). Peirce, bireyden hareketle toplumu, insan davranışlarını ve anlam yapısını incelemiştir. Kuramcı, sadece sözel işaretlerden bahsetmez aynı zamanda göstergenin oluşturulmasında bağıntının yeterli olmaması nedeniyle bireysel yorumun gerekliliğini vurgulamıştır (Echtner, 1999: 4).



Şekil 2. Peirce'ün Anlam Öğeleri

Kaynak: Fiske, 2014:125.

Peirce, Semiosis Süreci olarak tanımladığı süreci üçlü bir sistem üzerine oturtmuştur. Anlam sürecindeki bu sistem; gösterge ya da gösteren, nesne ve yorumlayacı şeklindedir. Nesne göstergenin yerini tutmaktadır. Yorumlayıcı, gösterge ile nesnesi arasındaki ilişkiyi üreten zihinsel süreçtir (Parsa ve Parsa, 2012: 11-12). Fiske (2014: 125) bu süreci birbiri ile ilişkili kavramlar olarak yorumlar. Gösterge; herhangi bir unsura gönderme yapar. Bireylerin zihninde bir etki oluşturur. Yorumlayıc1, uygun anlamlandırmayı sağlar. Gösterge ve kullanıcının nesne ile ilgili deneyimi tarafından üretilen zihinsel süreci ifade eder.

Göstergenin türsel ilişkisini belirleyen ilk küme nitel, tikel ve kavramsal göstergelerden oluşur. Nitel gösterge; ilk algıladığımız niteliktir. Bir başka deyişle sözcüğün ses dizimsel bağlamıdır. Tikel gösterge; belirli bir varlığa ya da duruma gönderme yapan göstergedir. Bir başka deyişle aitlik ya da belirtme bağlamıdır. Kavramsal/Kuramsal Gösterge ise göstergelerin temsil ettiği kavramı, genel özellikleriyle yansıtır (Işılar, 2014: 283). Gösterge türlerine ait ikinci küme görüntüsel gösterge, belirti ve simgeden oluşmaktadır. Benzerlik yoluyla işleyen görüntüsel göstergeler, mantıksal bağ yoluyla işleyen belirtisel göstergeler, tamamen uylaşımsal olan ve anlamlarının öğrenilmesi gerekeni simgeler. Hem görüntüsel hem belirtisel göstergeler yerine geçtikleri şeyle doğal bir bağa sahiptir. Örneğin portresi yapılan kişi ile portre (görüntüsel gösterge), yangını işaret eden duman ise belirtisel göstergedir (Berger, 2012: 86-87). Gösterge türlerine ait üçüncü küme ise terim, önerme ve sav unsurlarından oluşmaktadır. Terim ile kastedilen şey yorumlayıcı tarafından şekillendirilmesidir. Terimler doğru ya da yanlışlı̆ğ tek başlarına gösteremezler. İkinci olan önerme; bilgilenmeyi sağlamaktadır. Önermeler terimlerden oluşurlar. Savlar ise göstergelerin karmaşık halidir. Göstergeler arasında neden sonuç ilişkileri oluştururlar (Erkman-Akerson, 2016: 106-107).

\subsubsection{William Morris}

Morris genel olarak bütün göstergelerin genel bir kuramını ve işleyiş tarzını ortaya koymaya çalışmıştır. Bu genel kuramda üç temel işleyiş alanı vardır. Sözdizimsel boyut nasıl sorusuna yanıt arar. Göstergelerin kurallarını, diğer göstergeler ile etkileşimini ortaya koymaya çalışmaktadır. İkinci aşama ise anlambilimsel boyuttur. Göstergelerin ne anlama geldiğini, gösterge ile çağrışım sağladığı kavram arasındaki bağıntıyı ortaya koymaktadır. Son aşama edinbilimsel boyuttur. Gösterge ve yorumlayıcı arasındaki ilişkiyi incelemeyi 
gerektirmektedir (Rifat, 2014a: 122). Morris'in 1964 y1lında yayımlanan “Sings, Language and Behaviour" adlı eserinden Rifat (2014b: 238) tarafindan çevrilen bir kesitinde göstergebilim aşağıdaki gibi ifade edilmiştir:

"Göstergebilim, hayvanlarla ya da insanlarla ilgili, konuşulan ya da konuşulmayan, doğru ya da yanlış, yeterli ya da yetersiz, canlı ya da yozlaşmış bütün göstergelerin bilimidir. Göstergebilim bir bilim dalı olarak her bilimin sahip olduğu öneme sahiptir. Geliştikçe anlam belirten süreçlerle ilgili gitgide daha kesin bilgiler sunacaktır. Insanlar bu bilgileri çok sayıda kültürde yüzylllar süresince değişik biçimlerde edinmeye çalıştılar."

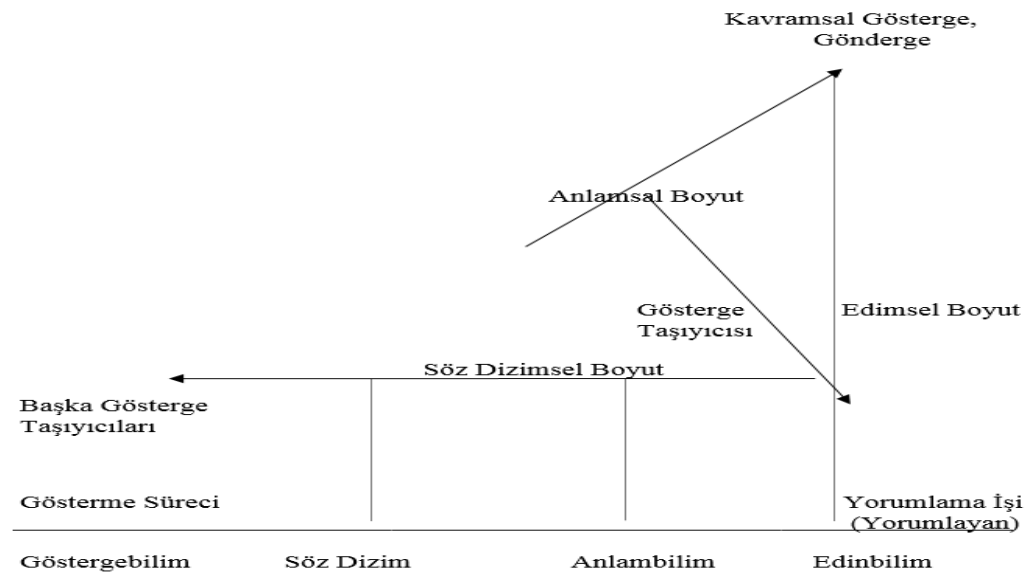

Şekil 3. Morris'in Gösterme Süreci

Kaynak: Erkman, 1986: 82.

\subsubsection{Algirdas Julien Greimas}

Fransa'da edebiyata göstergebilim açısından bakan ve Fransız göstergebilim okulunun en önemli temsilcilerinden sayılan Greimas, aslen Litvanyalı olup bir süre Türkiye'de de ders vermiştir (Erkman-Akerson, 2016: 133). Greimas anlamın üretiliş sürecini gösterengösterilen, anlatım düzlemi-içerik düzlemi arasındaki bağlantılara dayanarak yüzeysel yapı ve derin yapı olarak iki düzeyde ele alır. Yazınsal metin gibi görsel metin de iki düzlem eklemlenmesinden oluşur. Yüzeysel düzeyde görsel iletiyi oluşturan tüm öğeler derin düzeyde ise yüzeysel yapıda yer alan görüntülerin zihnimizde canlandırdığı kavramlar yer alır (Altınbüken, 2014: 240). İnsanın toplumsal yaşamı içinde ürettiği anlamlı bütünlerin incelendiği göstergebilimin en yöntemli ve en uzun soluklu yaklaşımını ortaya koyar (Öztokat, 2014: 137). Karşıtlıklar bağlantısını zıtlıklar oluşturmaktadır. Çelişkinlik ise bir nesneye ya da duruma ilişkin olumlu ve olumsuzlukları içerir. Örneğin; gece-gündüz bir karşıtllık oluştururken, olma-olmama bir çelişkenlik meydana getirir. Greimas'ın çözümlemesinin anahtarı, bir metindeki karşıtlıkların özdeşleştirilmesidir. Greimas'a göre yazıdaki anlam bütünüyle karşıtlıklar ya da tam belirlenmiş ayrılıklar yoluyla yaratılır. $\mathrm{Bu}$ karşıtlıklar, anlam yapısıyla anlamlama dizgelerindeki ayrıllı̆ı düzenleyen kuralları içeren kodlar tarafından sırayla yapılandırılmıştır (Gottdiener, 2005: 34). Greimas'ın çözümlemesinin anahtarı, bir metindeki karşıtlıkların özdeşleştirilmesidir. Greimas'a göre yazıdaki anlam bütünüyle karşıtlıklar ya da tam belirlenmiş ayrılıklar yoluyla yaratılır. $\mathrm{Bu}$ 
karşıtlıklar, anlam yapısıyla anlamlama dizgelerindeki ayrılığı düzenleyen kuralları içeren kodlar tarafından sırayla yapılandırılmıştır.

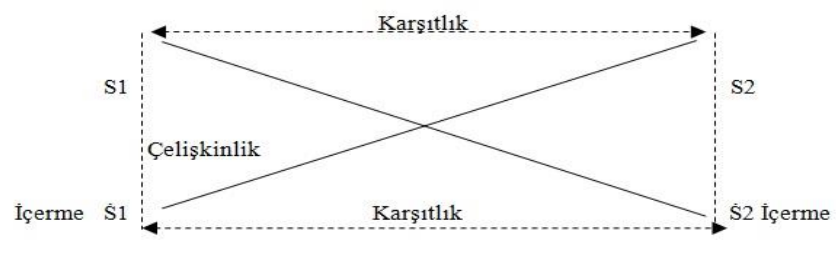

Şekil 4. Greimas Dörtgeni

Kaynak: Erkman-Akerson, 2016: 140.

\subsubsection{Roland Barthes}

Roland Barthes savaş sonrası dönemde ortaya çıkan çok önemli bir Fransız düşünürdür. 1945 ve 1980 yılları arasında Fransa dışında büyük bir entelektüel hareketin parçası haline gelerek, uluslararası üne sahip bir figür olmuştur. İlk başlarda diğer kuramcıların teorilerinden yararlansa da kendine özgü unsurları birleştirerek yeni bir teori oluşturmuştur. Başlangıçta ortaya attığı düşüncelerden uzaklaşarak yeni yollar sunmuştur. (Ribiere, 2008: 9). Barthes, geliştirdiği çözümlemeler ile yalnız edebi metinler için değil iletişim ve medya çalışmalarına da referans olmuştur (İnal, 2003: 10).

Barthes "Göstergebilimsel Serüven” (2016) kitabında göstergebilime ait üç evreden bahsetmektedir. Bunları birinci evre hayranlık evresi, ikinci evre bilim evresi, üçüncü evre metin evresi olarak siralamak mümkündür. Barthes hayranlık evresinde göstergebilimi ideolojik eleştirinin temel yöntemi olarak görmüştür. Bilim evresinde göstergebilimi bir sistem üzerine oturtmaya çalışmıştır. Son evre olan metin evresinde ise gösterene vurgu yapmıştır.

Gösterge kavramında en çok tartışılan gösterilendir. Gösterilen, kavram ile somut dünya ve kültür ilişkisini ortaya koymaktadır. Gösterilen, nesnelerin kopyası olmamakla birlikte nesnelerin soyutlanmasını kapsamaktadır. Bu sebeple kavramlar nesnelere bağlı olarak oluşsa da bir soyutlama sürecinden geçer (Parsa ve Parsa, 2012: 16).

\section{GÖSTERGEBİLIM ÇÖZÜMLEMELERİ}

Göstergebilim penceresinden baktığımızda yaşamımızı kuşatan bildiriler söz konusu olduğuna göre toplumsal yaşantılarımızda belki de en önemli etkinlik alanımızı, bildirileri çözümleme ve yeniden kurma süreçleri oluşturmaktadır (Öztokat, 2014: 135). Göstergebilim yöntemi ile dilsel, görsel ve işitsel bütüncelerde anlamın ekleniş ve üretilme süreci betimlenir. Göstergebilim, öykü, roman, şiir, tiyatro gibi yazınsal söylemlerin yanı sıra reklam, turizm, pazarlama ve siyasi söylemlerinin incelenmesinde, görsel sanatlar (resim, fotoğraf, heykel) sinema, animasyon, müzik, mimari düzenleme kent yapısı gibi insanın yarattığı anlam taşıyan tüm dizgelere uyarlanabilir (Altınbüken, 2014: 240).

Göstergebilim çözümlemeleri, inceleme aşamasında üç temel öğeyi gerektirmektedir. Bu öğeler; nesne, kullanılan göstergeler ve anlamdır. Üç unsur, birleşerek hedef kitleye verilmek istenen iletiyi oluşturur. $\mathrm{Bu}$ üç öğe ne kadar etkili bir biçimde kullanılırsa, hedef kitlenin 
bilinçaltına o denli etkili biçimde seslenilebilir. Etkisi yüksek olan dilsel ileti ve dilsel göstergelerle hedef kitleye seslenebilen reklam iletisi, yaptığı işi başarma açısından da önemli bir konumdadır. Reklam iletisinin dilsel ve görsel göstergelerden oluştuğu düşünülürse, reklamın çözümlenmesinde göstergelerin önemi daha iyi anlaşılmaktadır (Sığırcı, 2012: 97).

Göstergebilim alanında birbirinden farklı yönleri vurgulamaya yönelik yapılan çalışmalar vardır. Bu çalışmalar incelendiğinde göstergebilimin tek bir yöntem ve çalışma alanı ile sınırlı kalmadığı görülmektedir. Yapılan çözümlemeler daha çok Peirce, Saussure ve Barthes modellerinin uyarlanmaları yönünde olup her bir çözümleme de kendine özgü bakış açıları içermektedir.

İnsanlar göstergeler aracilı̆̆ıla birbirlerini anlar ve iletişime geçerler. Bir toplumun kültürü, o toplumun insanlarının birlikte yaşamasına olanak verir. Kültür de göstergelerden oluşan bir dizgedir. Bir kültürün göstergelerden oluşan bir bütünce olduğu söylenebilir. Bu bütünce kuşkusuz bir dizge niteliği taşımalıdır (Sayın, 2014: 63). Her toplum toplumsal ve tarihsel yaşam süreçleri içinde kendine özgü bir kültür oluşturur. Bu kültür aynı zamanda bu toplum tarafından üretilmiş göstergeler aracılığıyla ifade edilir. Her insan belirli bir toplum, kültür ve göstergeler dünyası içine doğar. Bu kültürü ve göstergeleri zaman içinde öğrenir ve böylece $o$ toplumun bir üyesi haline gelir (Sayın, 2014: 12) Kültürel göstergeler, diğer göstergeler gibi farklılıklar, zıtlıklar içinde anlam kazanır. Her kültürdeki göstergeler bu biçimde işler. Bir kültüre ait olan göstergeler kendi aralarında ilişki kurduğu gibi, diğer kültürlere ait göstergelerle de ilişki içindedirler. Bu sayede, iki kültüre ait değişik göstergeleri de birbirleriyle karşılaştırmak olasıdır (Günay ve Sönmez 2012: 112). İnsan iki büyük dizge tarafından kuşatılmış durumdadır: Doğa ve kültür. Bu iki dizgenin de temelinde bilgi yatmaktadır ama bilgilerin türleri daha doğrusu algılanma şekilleri farklıdır. Doğal dizgelerimizin taşıdığı bilginin bilincinde değiliz oysa kültür dizgelerinin taşıdığı bilginin bilincindeyiz (Erkman-Akerson, 2016: 29).Bir kültür ·ile toplumsallaştırılmış olmak, bir takım kodların öğretilmiş olduğu anlamına gelir. Tüm toplumsal ve kültürel etkinlikler veya ürünler kodlanmıştır (Parsa ve Parsa, 2012: 36).

Kişiler farklı medya kanalları aracılığıyla sürekli olarak görsel bir bombardıman altında kalırlar. Bu nedenle de görselleri kelimelerden daha sık görürler (Albakry ve Daimin, 2014: 28). Bu yaklaşım verili bir görüntüyü (bu bir filmden bir sahne ya da dergideki bir fotoğraf olabilir) temel unsurlarına ayırıp bu görüntüde anlamın nasıl inşa edildiğini bulmayı amaçlar. Aslında bir görüntü ilk anda göründüğünden daha fazla anlam taşır. Herhangi bir görüntüde üç temel unsur vardır (Burton, 2008: 24):

- Birincisi, görüntü elde edilirken kameranın nerede olduğudur. Bu, bizi yani izleyici, görüntüdeki nesnelere göre kendiliğinden belirli bir yere koyar.

- İkincisi, görüntü oluşturulurken kullanılan hilelerdir. Bu da her zaman görüntünün ne anlama geldiğine dair görüşümüzü etkiler. Sözgelimi yeni çekilmiş bir fotoğraf eski gibi görünmesi amacıyla (ve nostaljik bir hava versin diye) sepya tonlarında basılmış olabilir. Nitelik, 1şıklandırma, düzenleme, çerçeveleme resimde gerçekte ne olduğu hakkındaki kavrayışımızı etkileyen hilelerdir.

- Üçüncü unsur ise, görüntünün içeriği, burada yer alan nesnelerdir. İçerik çözümlemesi burada da ilginç noktalar ortaya çıkarabilir ve bizim görüntülere genellikle gereken dikkatle bakmadığımızı kanıtlar. 
Reklamların, afişlerin ve broşürlerin çözümlenmesini konu alan "görüntüsel çözümlemeler" (Çeken ve Yıldız, 2015; Kılınç, 2015; Oskay, 2015; Ulutaş ve Çevik, 2015; Güdekli, 2014; Güzeloğlu, 2014; Küçükerdoğan, 2014; Kükrer-Aydın, 2014; Olgundeniz ve Parsa, 2014; Sezer ve Sert, 2014; Yakın vd., 2014; Zeybek, 2014; Ardıç-Çobaner, 2013; Kirova ve Penkin, 2013; Naktan ve Logie, 2013; Küçükerdoğan, 2011; Öncel-Taşkıran, 2011; Yeygel ve Yakın, 2007; Güney, 2005; Baskan-Karsak, 2004) olarak sınıflandırılmıştır. Karikatür, tablo, resim, kitap kapağı, şiir, roman ve film gibi unsurların çözümlemesini içeren çalışmalar (Gariper, 2015; Korkut, 2015; Öztokat, 2015; Soğukkuyu, 2015; Altınbükün, 2014; Aktulum 2013; Kurtul, 2013; Sönmez, 2012; Turan, 2012; Sayar, 2013; Gökhan, 2011; Sivas, 2011; Arıkan, 2009; Çakır, 2009; Erdem, 2009; Karabulut, 2008; Soydan, 2007; Sarar-Kuzu, 2004) "sanatsal çözümlemeler" olarak sınıflandırılmıştır.

Tablo 1. Görüntü Çözümlemelerine İlişkin Çalışmalar

\begin{tabular}{|c|c|c|}
\hline Yıl & Araştırmacı(lar) & Bulgular \\
\hline 2018 & Civelek ve Türkay & $\begin{array}{l}\text { Elde edilen sonuçlar tanıtım görsellerin daha çok alternatif } \\
\text { turizm türlerine gönderme yaptığı yönünde olmuştur. S1klıkla } \\
\text { üzerinde durulan unsurlar "misafirperverlik, hoşgörü, } \\
\text { modernizm, geleneksellik ve doğu-batı sentezi" şeklinde } \\
\text { özetlenmiştir. }\end{array}$ \\
\hline 2015 & Çeken ve Yıldız & $\begin{array}{l}\text { Renk kullanımının reklamların algılanmasında üstlendikleri rol } \\
\text { üzerinde durulmuştur. Elde edilen sonuçlar } \\
\text { değerlendirildiğinde renklerin fiziksel ve psikolojik etkilerinin } \\
\text { iletilen mesajlar üzerinde etkisi olduğu ortaya konmuştur. }\end{array}$ \\
\hline 2015 & Soğukkuyu & $\begin{array}{l}\text { Çalışmada renkler, kullanılan sloganlar, görsel öğeler ve } \\
\text { ifadeler çözümlenmiş olup, zaman olgusuna vurgu yapıldığ1 } \\
\text { sonucuna varılmıştır. Aynı zamanda kadınların ruhsal ve } \\
\text { psikolojik özellikleri kapak resimlerinde yansıtılmıştır. }\end{array}$ \\
\hline 2014 & Altınbüken & $\begin{array}{l}\text { Araştırmada, şekillerin konumu, boyutu, yönü gibi unsuları göz } \\
\text { önünde bulundurulmuştur. Aynı zamanda renk kullanımı, } \\
\text { eserin okunma düzeyi, soyutluk düzeyi gibi hususlar da } \\
\text { vurgulanmıștır. }\end{array}$ \\
\hline 2014 & Bozkanat ve Kutluk & $\begin{array}{l}\text { Sloganların ve görsellerin, orta sınıf gelire sahip kitleye hitap } \\
\text { edecek şekilde tatilin bir lüks değil, bir ihtiyaç olarak } \\
\text { vurgulandığı görülmüş̧ür. Buna ek olarak görsellerde sılıkla } \\
\text { deniz imgesi kullanılmakla birlikte deniz terliği, güneş } \\
\text { gözlüğü, güneş kremi ve kum gibi deniz turizmine ilişkin } \\
\text { unsurların kullanıldığı sonucuna varılmıştır. }\end{array}$ \\
\hline 2014 & Sezer ve Sert & $\begin{array}{l}\text { İncelenen reklamlarda sıklıkla metaforlar kullanıldığı, anlatım } \\
\text { dilinin yumuşak ve anlaşılır olduğu sonucuna ulaşılmıştır. Buna } \\
\text { ek olarak çalışma kapsamında elde edilen sonuçlar } \\
\text { değerlendirildiğinde kamu spotlarında kullanılan dil ve } \\
\text { görüntülerin verilmek istenen mesajla örtüşmesi gerektiği } \\
\text { üzerinde durulmuştur. }\end{array}$ \\
\hline 2014 & Zeybek & $\begin{array}{l}\text { Mutluluk kelimesinden hareketle kullanılan sloganlar ve } \\
\text { görseller çözümlenmiştir. Elde edilen sonuçlar mutluluk } \\
\text { kavramı ile tüketicilere bunun aşılanmaya çalışıldığı, tüketime } \\
\text { katk1 sağladığı, bu kavramla işletme ve tüketici arasında } \\
\text { duygusal bir bağ kurulduğu yönünde olmuştur. }\end{array}$ \\
\hline 2013 & Kirovave Penkin & $\begin{array}{l}\text { İ̀sletmelere ilişkin logolar, semboller ve ilistrasyonlar } \\
\text { araştırılmıştır. }\end{array}$ \\
\hline 2013 & Sayar & İstanbul'a ilişkin görüşler ve bakış açısı yansıtılmıştır. Elde \\
\hline
\end{tabular}




\begin{tabular}{|c|c|c|}
\hline & & $\begin{array}{l}\text { edilen sonuçlara göre özlem duygusunun aktarılırken duyuların } \\
\text { ön plana çıarıldığı görülmüştür. }\end{array}$ \\
\hline 2012 & Sönmez & $\begin{array}{l}\text { Renklerin, kullanılan unsurların ve anlatılmak istenen } \\
\text { hikayenin incelendiği bu çalışmadan elde edilen sonuçlara göre } \\
\text { soyut resimlerin okunabilmesi için art alan bilgisine sahip } \\
\text { olunması gerekliliği üzerinde durulmuştur. }\end{array}$ \\
\hline 2012 & Turan & $\begin{array}{l}\text { Yedi ulusal gazetede yer alan karikatürlerin incelendiği } \\
\text { çalışmadan elde edilen sonuçlar partileri temsil eden parti } \\
\text { liderlerine yer verildiği, rekabet unsurunun sıklıkla kullanılidığ } 1 \\
\text { ve parti liderlerinin söylemlerine yer verildiği şeklinde } \\
\text { olmuştur. }\end{array}$ \\
\hline 2011 & Sivas & $\begin{array}{l}\text { Göstergebilimi kuramsal boyutta inceleme yaparak sinema ve } \\
\text { göstergebilim ilişkisini ortaya koymuştur. Metz, Eco ve Wollen } \\
\text { modelleri irdelenmiştir. Göstergebilim ve sinema etkileşimi bu } \\
\text { modellerle araştırılmıştır. }\end{array}$ \\
\hline 2005 & Güney & $\begin{array}{l}\text { İncelemeler hizmet özelliklerinin ön plana çıarıldığı, bilgi } \\
\text { verme amacı taşıdıkları, hedef kitlenin özellikleri göz önünde } \\
\text { bulundurularak dilsel ve görsel öğelerin kullanıldığ } \\
\text { yönündedir. }\end{array}$ \\
\hline 2004 & Baskan-Karsak & $\begin{array}{l}\text { Görsel kimlik göstergelerinin renklerin kullanımı da göz } \\
\text { önünde bulundurularak firma tarafından verilmek istenen mesaj } \\
\text { doğrultusunda bilinçli olarak seçildiği sonucuna varılmıștır. }\end{array}$ \\
\hline
\end{tabular}

\section{SONUÇ ve DEĞERLENDİRME}

Göstergebilim son zamanlarda üzerinde sıklıkla çalışılan bir konu haline gelmiştir. Göstergebilimin inceleme alanı geniş olduğundan araştırmacılar tarafindan kuramcıların çözümlemeleri yol gösterse de yeni okuyuş biçimleri de sağlamıştır. Bu okuyuş biçimleri göstergebilimin daha geniş bir perspektiften incelenmesini beraberinde getirmiştir. Göstergebilim, görünen anlamın dışındaki derin anlamın çözümlenmesidir. Gerek kültürel kodlar gerekse göstergeler aracılığıyla anlamın nasıl inşa edildiğine ilişkin göndermeler yapar. Anlamın inşa sürecinde, anlamın ne olduğundan çok nasıl oluştuğu ile ilgilenir. Anlamlandırma sürecini parçalara ayırarak bütünü görmeyi hedeflemektedir. Barthes'ın "Göstergebilimsel Serüven," Saussure'1n ise "Semiosis Süreci” olarak nitelendirdiği çözümleme süreci göstergebilimin gelişimini ve metinlerin okuyuş biçimlerini şekillendirmiştir. Kuramcıların bakış açıları göstergebilimi bir yöntem olmaktan ziyade bir disiplin olarak ele almayı da sağlamıştır.

Göstergebilim, "göstergelerin bilimi" olduğundan hemen her alanda göstergebilimsel çözümlemeler yapmayı mümkün kılar. Karikatürlerden müzik notalarına, şiirden sinema filmlerine, tablolardan kamu spotlarına, iletişimden pazarlamaya kadar geniş bir alana yayılmıştır. Göstergebilimin tek bir alana bağlı olmaması ortak kodların gelişmesini de beraberinde getirmiştir. Renkler, beden dili, jest ve mimikler, davranış biçimleri gündelik hayatta kullanılan unsurlar göstergebilimin inceleme alanına girer. Bunun yanı sıra göstergebilim çözümlemelerinin kültürel kodlar ile ortak çıkarımlar yapmayı da sağlamaktadır.

Bu çalışmada göstergebilim, kuramsal açıdan ele alınmıştır. Göstergebilimin kuramsal açıdan bir bütün halinde değerlendirilmesi, göstergebilim konusunda yeni çalışmalar yapacak olan araştırmacılara yön gösterceği düşünülmektedir. Özellikle kuramcıların göstergebilime ilişsin 
çözümlemelerinin bir payda altında toplanması daha sonraki araştırmalara kolaylık sağlayacaktır. Göstergebilim konusunda uluslararası düzeyde yapılan çalışmalar çeşitlilik gösterse de ulusal düzeyde yapılan çalışmalar daha çok pazarlama ve iletişim ağırlıklıdır. Bu nedenle ulusal düzeyde yapılması olan çalışmaların farklı alanlarda göstergebilimsel çözümlemeler yapmalı alanyazına katkı sağlayacaktır.

\section{KAYNAKÇA}

AKTULUM, K. (2004). “Göstergebilim”. Süleyman Demirel Üniversitesi Burdur Eğitim Fakültesi Dergisi, 5: 1-13.

AKTULUM, K. (2013). "Tahsin Yücel'in Yalan Adlı Romanında Yapısal Dilbilimin ve Göstergebilimin İzleri”. Turkish Studies-International Periodical for the Languages Literature and History of Turkish or Turkic, 8(13): 1-11.

ALBAKRY, S. M. \& DAIMIN, G. (2014). “The Visual Rhetoric in Public Awareness Print Advertising Toward Malaysia Perceptive Sociolculture Design". Procedia-Social and Behavioral Sciences, 155: 28-33.

ALTINBÜKEN, B. (2014). “Göstergebilim Yöntemiyle Görsel Sözce Çözümlemesi”. A. Güneş (Ed.). İletişim Araştırmalarında Göstergebilim Yazınsaldan Görsele Anlam Arayış1 (239-258). Literatür Academia, Konya.

ARDIÇ-ÇOBANER, A. (2013). "Sağlık İletişiminde Korku Öğesinin Kullanımı: Sigara Paketlerinde Kullanılan Sigara Karşıtı Görsellerin Göstergebilimsel Analizi”. İletişim Kuram ve Araştırma Dergisi, 37: 211-235.

ARIKAN, S. (2009). “Göstergebilimsel Bir Çözümleme: Samuel Richardson’ın Pamela’sı”. Atatürk Üniversitesi Sosyal Bilimler Enstitüsü Dergisi, 13(2): 147-160.

BARTHES, R. (2016). Göstergebilimsel Serüven. Yapı Kredi Yayınları, İstanbul.

BASKAN-KARSAK, B. (2004). "Görsel Kimlik Göstergeleri Açısından Arçelik Firması Web Sayfası İncelemesi”. İletişim Dergisi, 1(1): 99-114.

BERGER, A. A. (2012). Kültür Eleştirisi: Kültürel Kavramlara Giriş. Pinhan Yayınevi, İstanbul.

BERKELEY, J. (2012). Insights in Linguistics and Semiotics: Semiotics of Discourse. Peter Lang Publishing Inc, New York.

BOZKANAT, E. \& KUTLUK, A. (2014). "Göstergebilim Bağlamında Reklam Çözümlemesi: Seyahat Acentelerinin Online Erken Rezervasyon Görselleri”. 1st International Congress of Tourism \& Management Researches-2014.

BURTON, G. (2008). Görünenden Fazlası. Alan Yayıncılık, İstanbul.

CIVELEK, M. \& TÜRKAY, O. (2018). “Türkiye Tanıtım Afişlerinin Göstergebilimsel Bir Analizi: Home of Turkey Afişleri Örneği”. The Turkish Online Journal of Design, Art and Communication, 8 (2): 312-328.

ÇAKIR, M. (2009). “Bir Göstergebilimsel Çözümleme: Daniel Defoe’nun Moll Flanders'1”. Atatürk Üniversitesi Sosyal Bilimler Enstitüsü Dergisi, 13(2): 131-145. 
ÇEKEN, B. \& YILDIZ, E. (2015). "Renklerin Reklam Algısı Üzerindeki Etkisi: 2012 Kırmızı Reklam Ödülleri”. Sanat Eğitim Dergisi, 3(2): 129-146.

ÇIÇEK, M. 2014. “Dilbilimsel İlkeler Görsel Göstergelere Uygulanabilir Mi?” Uluslararası Sosyal Araştırmalar Dergisi, 7(32): 38-51.

ECHTNER, C. M. (1999). “The Semiotic Paradigm: Implications for Tourism Research". Tourism Management, 20: 47-57.

ECO, U. (2004). Avrupa Kültüründe Kusursuz Dil Arayışı. Literatür Yayıncılık, İstanbul.

ELGÜN, A., BABACAN, E., KOZAK, M. \& BABAT, D. (2013). "Yeni Tüketim Mekanları Olarak Havalimanı Terminalleri”. Anatolia Turizm Araştırmaları Dergisi, 24(1): 7082.

ERDEM, M. D. (2009). “Göstergebilim (Semiotik) Açısından Rasim Özdenören'in İt Hikâyesi”. Turkish Studies International Periodical for the Languages, Literature and History of Turkish or Turkic, 4(6):120-169.

ERKMAN, F. (1986). Göstergebilime Giriş. Alan Yayıncılık, İstanbul.

ERKMAN-AKERSON, F. (2016). Göstergebilime Giriş. Bilge Kültür Sanat, İstanbul.

FISKE, J. (2014). İletişim Çalışmalarına Giriş. Pharmakon Yayınevi, Ankara.

GARIPER, C. (2015). “Cengiz Aytmatov’un Al Yazmalım Selvi Boylum Hikâyesi ve Göstergelerarasılık”. Bilig, 74: 71-96.

GOTTDIENER, M. (2005). Postmodern Göstergeler. İmge Kitapevi, Ankara.

GÖKHAN, A. (2011). "Sadık Hidayet'in Lale Adlı Öyküsüne Göstergebilimsel Bir 299-309. Yaklaşım”. Atatürk Üniversitesi Sosyal Bilimler Enstitüsü Dergisi, 15(1):

GUIRAUD, P. (1994). Göstergebilim. İmge Kitapevi, Ankara.

GUIRAUD, P. (1999). Anlambilim. Multilingual, İstanbul.

GÜDEKLI, A., EHTIYAR, R., GÜZEL, Ö. \& ERSOY, A. (2015). “Turizme Yönelik Tanıtım Afişlerinde İmge Olarak Kadın: Göstergebilimsel Bir Analiz”. 16. Ulusal Turizm Kongresi, 12-14 Kasım 2015, Çanakkale.

GÜNAY, D. (2002). Göstergebilim Yazıları. Multilingual, İstanbul.

GÜNEY, Z. (2005). "Bant Reklamlarının Analizi: Telsim Bant Reklamları Örnekleri”. Galatasaray Üniversitesi İletişim Dergisi, 3: 133-152.

GÜZELOĞLU, C. (2014). “Türkiye'de Moda Markalarının Göstergelerle Anlatıları: Ödüllü Moda Reklamlarının Görsel İletişim Tasarımına Yönelik Çözümleme”. Uluslararası Sosyal Araştırmalar Dergisi, 7(3): 747-762.

IŞIKLAR, G. (2014). “Bir Aşk Söyleminde Görüntüyü Okumak: Aşk Tesadüfleri Sever”. A. Güneş (Ed.). İletişim Araştırmalarında Göstergebilim Yazsınsaldan Görsele Anlam Arayışı (280-298). Literatür Academia, Konya. 
İNAL, A. (2003). "Roland Barthes: Bir Avant-Garde Yazarı". Ankara Üniversitesi İletişim Araştırmaları Dergisi, 1(1): 9-38.

KARABULUT, F. (2008). “Bir Gösteren Olarak Beden ve Dili: Göstergebilim Çerçevesinde Göç Romanı ve Dede Korkut Hikayeleri’nin İncelenmesi’. Türk Kültürü ve Hacı Bektaşı Veli, 48: 69-90.

KILINÇ, Ö. (2015). “Reklamlarda Erkeklik: GQ ve Men’s Health Dergilerindeki Reklamların Eleştirel Bir Okuması”. Journal of Yasar University, 10(37): 6381-6477.

KIRAN, A. (2004). “Göstergebilim ve Yazınsal Çözümlemeler”. N. Tanyolaç Öztokat (Ed.). Disiplinlerarası Ortam ve Yöntem Sorunlar. (50-61). Multilingual, İstanbul.

KIRAN, A. (2009). “Çağdaş Bir Düşünme Biçimi Olarak Göstergebilim”. Dilbilim, 2(2): 1 16.

KIROVA, B. \& PENKIN, I. (2013). "The Name of The Thing, or an Attempt at a Semiotic and Semantic Analysis of Trade Marks". Journal of Intellectual Property Law and Practice, 8(4): 297-302.

KORKUT, E. (2015). “Göstergebilimsel Çözümleme: Tembel Adam Masalı”. Millî Folklor, 27(108): 74- 83.

KURTUL, K. (2013). “Cellât ve Ağlayan Yüz Adlı Hikâyenin Göstergebilimsel Açıdan Çözümlemesi”. The Journal of Language and Linguistic Studies, 9(1): 81-94.

KÜÇÜKERDOĞAN, R. (2011). "Dilinizden Utanmayın Reklam Kampanyasının Göstergebilimsel Açıdan Çözümlemesi”. The Turkish Online Journal of Design Art and Communication, 1(1): 26-34.

KÜÇÜKERDOĞAN, R. (2014). "Gerçek Güzellik ya da Gerçek Yalanlar Reklamlar Aracılığıyla Tüketilen Güzellik ve Göstergeler”. A. Güneş (Ed.). İletişim Araştırmalarında Göstergebilim Yazınsaldan Görsele Anlam Arayışı (49-70). Literatür Academia, Konya.

KÜKRER-AYDIN, Ö. (2014). "Televizyon Reklamlarında Dizi Karakteri Kullanımıyla Sunulan Tüketim Kültürü Değerleri: Yalan Dünya Örneği”. Journal of Yasar University, 9(36): 6261- 6380.

MACCANNELL, D. (2013). The Tourist: A New Theory of the Leisure Class. University of California Press, London.

NAKTAN, M. \& NACAR-LOGIE, N. (2013). "Reklam Ürünlerinde Toplumsal Sınıfların Tanitımı". International Periodical for The Languages, Literature and History of Turkish or Turkic, 8(10): 459-467.

OLGUNDENIZ, S. S. \& PARSA, A. F. (2014). "Reklam Dünyasında İmgenin Gücü Arçelik ve Vestel Reklamlarında Robot Karakterlerle Yaratılan Evren”. E-Journal of New World Sciences Academy, 9(2): 95-106.

OSKAY, A. H. (2015). “Televizyon Reklamlarında Çocuk İmgesinin Göstergebilimsel Analizi”. Online Academic Journal of Information Technology, 6(19): 109-126. 
OSWALD, R. L. (2011). Marketing Semiotics: Sings, Strategies and Brand Value. Oxford University Press, New York.

ÖNCEL-TAŞKIRAN, N. M. (2011). "Reklamın Mizahi Çerçevede Ünlü Kişi Aracılığıyla Sunumu: Ürün Nesne İlişkisinde İmaj Aktarımı”. Atatürk Üniversitesi İletişim Fakültesi Ulusal İletişim Kongresi, Gülmenin Arkeolojisi ve Medyada Mizah Olgusu Bildiriler Kitab1, 1-14.

ÖZTOKAT, N. (2014). “Anlam Alanı Olarak Özne ve Beden”. A. Güneş (Ed.). İletişim Araştırmalarında Göstergebilim Yazınsaldan Görsele Anlam Arayışı (135-154). Literatür Academia, Konya.

PARSA, A. F. (2007). “Göstergenin Gücü/Gücün Göstergesi: İmge Reklam Bildirilerinde Göstergebilimsel Yaklaşımla Durağan İmgeleri Çözümlemek”. VII. Uluslararası Görsel Göstergebilim Kongresi, AISV-IAVS Görünürün Kültürü. İstanbul Kültür Üniversitesi Yayınlar1, 63(2): 1-10.

RIBIERE, M. (2008). Barthes. LLP Humanities-Ebooks: CA.

RIFAT, M. (2014a). XX. Yüzyılda Dilbilim ve Göstergebilim Kuramları-1 Tarihçe ve Eleştirel Düşünceler. Yapı Kredi Yayınları, İstanbul.

RIFAT, M. (2014b). XX. Yüzyılda Dilbilim ve Göstergebilim Kuramları-2 Temel Metinler. Yapı Kredi Yayınları, İstanbul.

RIFAT, M. (2013). Açıklamalı Göstergebilim Sözlüğü: Kavramlar, Yöntemler, Kuramcılar, Okullar. Türkiye İş Bankası Kültür Yayınları, İstanbul.

RIFAT, M. (2011). Homo Semioticus ve Genel Göstergebilim Sorunları. Yap1 Kredi Yayınları, İstanbul.

SINAN, T. A. \& DEMIR, S. (2010). “Göstergebilimsel Yöntemler Işı̆̆ında Deniz Bank Reklamının Okunması". International Periodical for The Languages, Literature and History of Turkish or Turkic, 5(2): 1313-1332.

SEZER, N. \& SERT, Y. N. (20149. “TV Kamu Spotu Reklamlarının Medya Okuryazarlığ1 Çerçevesinde Kullanılması: Çocuk ve Medya Hareketi. TV Kamu Spotu Reklamının Göstergebilimsel Çözümlenmesi”. A. Güneş (Ed.) İletişim Araştırmalarında Göstergebilim (11-48). Literatürk Yayınları, Konya.

SAYAR, E. (2013). “Orhan Veli'nin İstanbul'u Dinliyorum Şiiri Üzerinden İstanbul'u Göstergebilimsel Okumak". Turkish Studies International Periodical for the Languages, Literature and History of Turkish or Turkic, 8(9): 2185-2200.

SAYIN, Ö. (2014). Göstergebilim ve Sosyoloji. Anı Yayınevi: Ankara.

SIĞIRCI, İ. (2012). “Göstergebilimsel Açıdan Reklam İncelenmesi: Bir Otomobil Reklamı” . D. Günay ve A. F. Parsa (Ed.). Görsel Göstergebilim İmgenin Adlandırılması (96106). Es Yayınları, İstanbul.

SIVAS, A. (2011). "Göstergebilim ve Sinema İlişkisi Üzerine Bir Deneme”. İstanbul Ticaret Üniversitesi Sosyal Bilimler Dergisi, 21: 527-538. 
SOĞUKKUYU, B. (2015). “Kitap Kapağı Tasarımında Kadın Portresinin Kullanımı”. Uşak Üniversitesi Sosyal Bilimler Dergisi, 8(1): 57-72.

SOYDAN, M. (2007). "Yavuz Turgul'un Gönül Yarası Filminin Greimas’ın Eyleyensel Örnekçesine Göre Çözümlenmesi”. Sosyal Bilimler Dergisi, 18: 1-15.

SARAR-KUZU, T. (2004). “Greimas'ın Eyleyenler Modeli’nin, Bir Durum-Kesit Öyküsündeki İşlerliğine İlişkin Göstergebilimsel Çözümleme Denemesi’. Dil Dergisi 124: 34-52.

SÖNMEZ, Ö. (2012). "Soyutlamacı Resmin Okunmasına Göstergebilimsel Bir Yaklaşım”. Süleyman Demirel Üniversitesi, 9: 1-21.

TURAN, M. O. (2012). “Gazetelerde Yayınlanan Siyasi Karikatürlerin Göstergebilimsel Çözümlemesi”. Selçuk İletişim, 7(2): 1-19.

ULUTAŞ, S. \& ÇEVIK, K. S. (2015). "Propaganda Amaçlı Belgesel Basın Fotoğraflarının Anlam Sorunu ve Fotoğrafların Göstergebilimsel İncelenmesi”. İnönü Üniversitesi Kültür ve Sanat Dergisi, 1(2): 25-39.

ÜNAL, S. (2014). Göstergebilimsel Açıdan Sembolik Tüketim. Detay Yayıncılık, Ankara.

VARDAR, B. (1982). Dilbilimin Temel Kavram ve İlkeleri. Türk Dil Kurumu Yayınları, Ankara.

YAKIN, V., YAKIN, C. \& YAKIN. M. (2014). "Reklamlarda Kullanılan Marka Kişilik Arketiplerinin Göstergebilimsel Analizi”. Yönetim ve Ekonomi Dergisi, 21(1): 345355 .

YEYGEL, S. \& YAKIN, M. (2007). "Kurumsal Reklamlarda Göstergeler Aracılı̆̆ıyla Marka Kimliğinin İletilmesi”. Selçuk İletişim Dergisi, 5(1): 102-117.

YÜCEL, T. (2012). Eleştiri Kuramları. Türkiye İş Bankası Kültür Yayınları: İstanbul.

ZEYBEK, I. (2014). “İletişim Araştırmalarında Göstergebilim, İçinde Reklamlarda Mutluluğa Davet Var”. A. Güneş (Ed.). İletişim Araştırmalarında Göstergebilim Yazınsaldan Görsele Anlam Arayışı (49-70). Literatür Academia, Konya. 